\title{
Charcot-Marie-Tooth Disease and Posterior Scleritis. A Case Report
}

\author{
Doença de Charcot-Marie-Tooth e esclerite posterior. Relato de caso
}

\author{
Elisabeth N. Martins \\ André C. Branco \\ Lênio S. Alvarenga \\ Fausto Uno \\ Nilva B. Moraes \\ Rubens Belfort Jr.
}

\section{SUMMARY}

Purpose: To describe the unusual association of Charcot-MarieTooth disease (CMTD) and posterior scleritis.

Methods: Case report of a 16-year-old female with decreased visual acuity and pain in both eyes.

Results: Ophthalmologic examination showed a posterior scleritis, confirmed by ultrasound and angiofluoresceinography. Foot deformities and sensory dysfunction were identified in the patient and some of her relatives. The diagnosis of CMTD in this patient was confirmed by eletrophysiologic studies.

Conclusions: The association of posterior scleritis in a patient with CMTD has never been reported. This is also the first description of an inflammatory ocular disease in these patients.

Keywords: Charcot-Marie-Tooth disease; Posterior scleritis.

Charcot-Marie-Tooth encompasses a group of inherited neuropathies characterized by a slowly progressive muscular atrophy with weakness and wasting of feet and leg muscles followed by hand involvement, first described in $1886^{1}$.

\section{CASE REPORT}

Sixteen-year-old, black, female presented with decreased visual acuity and ocular pain in both eyes for one week.

The ocular examination revealed a bilateral proptosis and the corrected visual acuity was 0.6 in the right eye and 0.1 in the left eye. Intraocular pressure and biomicroscopy were normal. Pupillary reflexes were slightly decreased in both eyes. Fundoscopy revealed bilateral serous retinal detachment in the posterior pole (Figure 1A).

Wasted legs with an "inverted champagne bottle" appearance were detected on the physical examination. Hammer toes, equinovarus feet and calluses over the pressure points were also present as well as muscle weakness and sensory dysfunction. Muscle stretch reflexes were absent. The familiar history showed similar foot deformities in her grandmother, uncles and father (Figure 2).

An elevated $(65 \mathrm{~mm})$ first-hour sedimentation rate was observed. Ultrasound (Figure 1B) and the angiofluoresceinography confirmed the diagnosis of bilateral posterior scleritis.

The patient underwent eletrophysiologic studies that showed undetectable action potentials in the median, ulnar and sural sensory nerves. Prolonged distal latencies and reduced conductional velocities were 


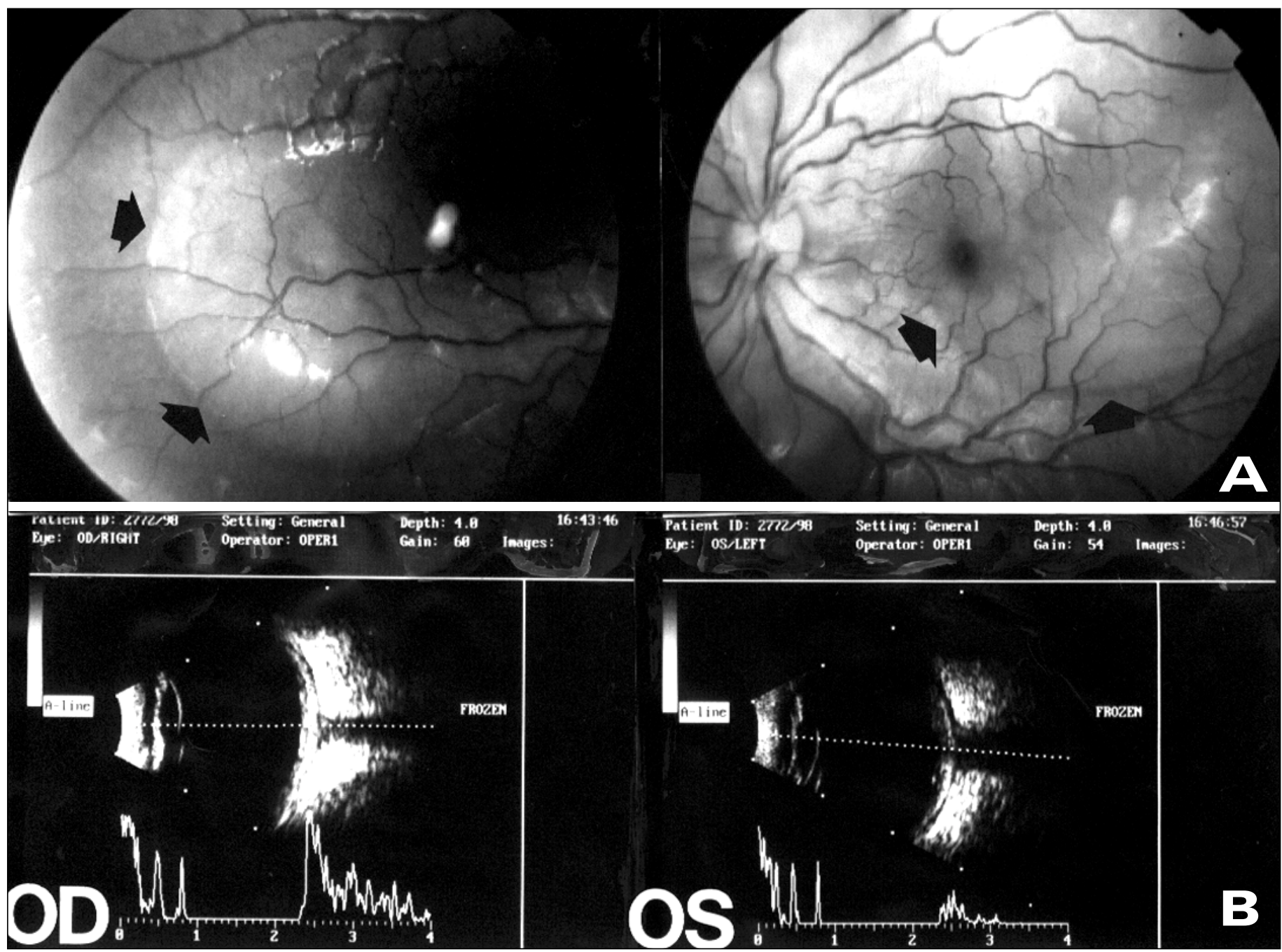

Fig. 1- A (top). Retinography showing serous retinal detachment. B (bottom) Ultrasonogram showing scleral thickening, tenonitis and characteristic "T" sign.

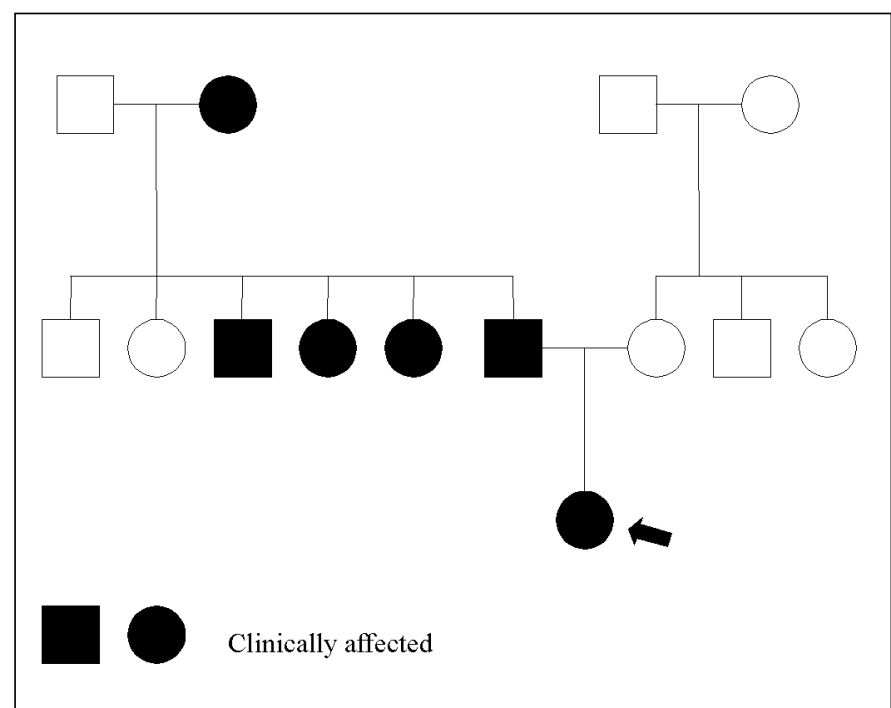

Fig. 2 - Pedigree of the patient's family with Charcot-Marie-Tooth disease. detected by motor conduction studies in the median, ulnar, tibial and fibular nerves.

The patient was treated with oral indomethacin $(100 \mathrm{mg}$ per day/two doses) for two weeks. On the third day of treatment, pain had decreased considerably, with total resolution in a week. By the end of the treatment visual acuity was 1.0 in both eyes.

\section{DISCUSSION}

Ocular manifestations such as pupillary abnormalities, premature presbyopia, retinitis pigmentosa, optic atrophy and nystagmus have previously been described in patients with CMTD $^{2,3}$. Secondary ocular involvement (ptosis and diplopia) in patients with CMTD affected by myasthenia gravis ${ }^{4,5}$ has also been reported. All of these ocular abnormalities were ruled out in this patient.

The typical clinical presentation of the motor and sensory 
abnormalities affecting this patient are consistent with CMTD. Motor and sensory conduction studies of the patient, the similar clinical findings in the affected relatives and the dominant pattern of inheritance (Figure 2) confirmed this diagnosis.

Some studies have inferred that inflammatory processes may play a role in the expression of CMTD. The improvement with prednisone therapy may reflect an associated inflammatory demyelinating process ${ }^{6}$. An experimental study in rats has shown that Schwann cell-derived progesterone promotes myelin formation during nerve regeneration, this being an evidence that steroids could affect the expression of myelin genes responsible for the phenotype of CMTD ${ }^{7}$.

Ocular involvement in patients with CMTD is uncommon and this is the first report of bilateral posterior scleritis in these patients. Despite the possible influence of inflammation in the expression of this disease inflammatory disorders are not frequently associated.

\section{RESUMO}

Objetivo: Descrever a associação entre doença de CharcotMarie-Tooth (DCMT) e esclerite posterior.

Metodologia: Relato de caso de uma paciente do sexo feminino, 16 anos de idade, com baixa de acuidade visual e dor em ambos os olhos.

Resultados: $O$ exame oftalmológico revelou esclerite poste- rior, observada também por ultra-som e angiofluoresceinografia. Deformidades de pernas e pés foram identificadas na paciente e em seus familiares. $O$ diagnóstico de DCMT na paciente estudada foi confirmado por estudos eletrofisiológicos.

Conclusões: A presença de esclerite posterior em paciente com DCMT não é descrita na literatura, não se encontrando também relatos de outras doenças oculares inflamatórias, nestes pacientes.

Palavras-chave: Doença de Charcot-Marie-Tooth; Esclerite posterior.

\section{REFERENCES}

1. Dyck PJ, Chance P, Lebo R, Carney JA. Hereditary motor and sensory neuropathies. In: Griffin JW, Low PA, Poduslo JF, eds. Peripheral Neuropathy. Philadelphia: W.B.Saunders Company, 1993.p.1094-136.

2. Keltner JL, Swisher CN, Gay AJ, Hepler RS. Myotonic pupils in CharcotMarie-Tooth disease. Arch Ophthalmol 1975;93:1141-8.

3. Hoyt WF. Charcot-Marie-Tooth disease with primary optic atrophy: report of a case. Arch Ophthamol 1960;64:925-8.

4. Berger JR, Ayyar DR, Kimura I, Kovacs A. Myasthenia gravis complicating Charcot-Marie-Tooth disease: report of a case. J Clin Neuroophthalmol 1985;5:76-80.

5. Chen CM, et al. Myasthenia gravis and Charcot-Marie-Tooth disease type 1A: an unusual combination of diseases. Muscle Nerve 1997;20:1457-94.

6. Dick PJ, Low PA, Bartelson JD. Prednisone responsive hereditary motor and sensory neuropathy. Mayo Clin Proc 1982;47:239-42.

7. Koening HL, Schumacher M, Ferzaz B et al. Progesterone synthesis and myelin formation by Schwann cells. Science 1995;268:1500-3

\section{Simpósio da Sociedade Brasileira de Glaucoma}

\section{7 a 9 de Junho de 2001}

\section{Minascentro - Belo Horizonte - MG}

INFORMAC̣ÕES: Consult Comunicação e Marketin

Av. Agusto de Lima, 479-Cj. 1611

CEP 30190-000 - Belo Horizonte -MG

Telefax: (00xx31) 3274-1550

E-mail: comunica@consultcom.com.br

http://www.cbo.com.br/abo 